\title{
Bilgi Ekonomisi Değişkenlerine Yönelik İlk İzlenimler: Türkiye- OECD Ülkeleri Karşılaştırmaları (1995-1999)*
}

\author{
First Impressions on Information Economic Variables : \\ A Comparative Study between Turkey and OECD Countries (1995-1999)
}

Hakkı Okan YELOĞLU*

\begin{abstract}
Öz
Bilgi ekonomisinin özellikle 1990’'ı yılların sonlarına doğru artan önemi, farklı araştırma sorularının gündeme gelmesine neden olmuştur. Bu çalışma, hem bilgi ekonomisi göstergelerini oluşturan değişkenlerin neler olabileceğini ele almakta ve hem de Türkiye'yi diğer ülkelerle karşılaştıran bir konumlandırma yapmayı amaçlamaktadır. Böylece, bilgi ekonomisi bağlamında, Türkiye'nin zaman içerisinde bilgi ve iletişim teknolojileri faaliyetleri bakımından hangi ülkelerle benzerlik gösterdiği ortaya konulmaya çalışılmıştır. Bu amaca yönelik olarak çalışmada, Organisation for Economic Co-operation and Development (OECD)'nin bilgi ekonomisinin varlığını ölçmede kullandığı kriterler göz önünde bulundurularak görgül bir çalışma yürütülmüştür. Çalışmada, çok değişkenli istatistiksel yöntemlerden biri olan kümeleme analizinin kullanılması ile elde edilen bulgulara göre, Türkiye'nin, yıllar itibariyle gösterdiği gelişme yönünden daha çok Kuzey Avrupa ülkeleri ile benzeştiği tespit edilmiştir.
\end{abstract}

Anahtar sözcükler: Bilgi ekonomisi, OECD, Türkiye

\begin{abstract}
The gradual growth in the importance of Information Economics, especially in late 1990s; has led to different research inquiries along with broadened study fields. In addition, there have been continuous disputes on subjects like; how "an information economy" should be defined theoretically, and with which variables can its intensity and characteristics be measured. Thereby, this study covers both the possible variables that build up the information technology, and also it aims to set forth a positioning, by means of comparing Turkey with other countries. Furthermore, in the context of information technology, it has been intended to designate Turkey's resemblance to other countries in due course, in
\end{abstract}

\footnotetext{
* Makalenin kısa versiyonu 25-26 Kasım 2004'te 3. Eskişehir Osmangazi Üniversitesi tarafından düzenlenen 3. Ulusal Bilgi Ekonomi ve Yönetim Kongresi'nde sunulmuştur.

*Dr.; Başkent Üniversitesi, Fen Edebiyat Fakültesi, İstatistik ve Bilgisayar Bilimleri Bölümü, Bağlıca Kampusu, Ankara. (okany@baskent.edu.tr)
} 
terms of its information and communication-based technological activities. This study conceives OECD's (Organisation for Economic Co-operation and Development) criteria for an information economy assessment, and conducts an empirical research. Throughout the study, it has been identified that, in terms of the progress exhibited by Turkey mostly bears resemblance to North European countries, according to the findings which were obtained by using hierarchical cluster analysis.

Keywords: Information economy, OECD, Turkey

\section{Giriş}

Ülkelerin ekonomik, toplumsal, siyasal gibi farklı alanlarda ve teknolojide gösterdikleri gelişimler nedeniyle kendilerini yeniden tanımlamaları intiyacı belirmiştir. Aynı zamanda ülkeler, gelişmiş, gelişmekte olan ve geç gelişen diye sınıflandırıldıklarında kendi dinamikleri de öne çıkmaktadır. Son yıllarda, sanayi toplumunun kilit kavramı olan üretimden, bilgi ve iletişim teknolojileri gibi kavramlara geçişte farklı boyutların ortaya çıkışı dikkat çekmektedir. Yaşanan sözkonusu gelişmelerin yanısıra, gittikçe kızışan pazar koşulları, rekabet ve ekonomilerin değişkenlik göstermeleri de, ülkelerin birbirleri ile kıyaslanabilmesi açısından büyük önem taşımaktadır. Diğer yandan, ulusal anlamda ortaya çıkan değişikliklerde de son yıllarda anlamlı bir dinamizm yaşanmaktadır. Bazı sektörler kendilerine has önemlerini yitirirken, uygulamaya yönelik, yüksek kâr marjlı kimi yeni sektörlerin ortaya çıkışı ve bu sektörlerin hızla uluslararası bağlamda yayılması, hem ekonominin hem de rekabetin tanımlanmış olan boyutlarını da değiştirmektedir. Eski sektörler rekabet alanlarını, kârıııklarını ve çalışan kişi sayılarını yitirirken, özellikle teknolojik gelişmelere açık yeni sektörler cazip hale gelmekte, kendi iş imkânlarını kendileri doğurmakta ve çalışan kişi sayısında yüksek bir artışa neden olmaktadırlar. Ayrıca internet, telekomünikasyon ve bilgi teknolojilerinin daha fazla kullanılması; etkinlik, etkililik, verimlilik, girdi-çıktı, hizmetlerin sunumu, kalitesi ve kârılık kavramlarına yeni bir bakış açısı getirmektedir. Böylece adı geçen teknolojiler, klasik ekonominin temel dayanaklarını sorgular hale getirmiştir. Bu gelişmelere ek olarak küreselleşmenin ön plana çıkması, özellikle iletişim ve bilişim sektörü başta olmak üzere birçok yeni sektörün pazarda liderliği elinde tutmasına yol açmış ve "yeni" ekonominin değişkenleri üzerinde rol oynamalarına neden olmuştur.

Bilgi ve teknolojiye dayanan yeni ekonomi koşullarının günlük yaşamı da değiştirdiği açıktır. Her türlü iletişimin dijital yollarla yapılması, ticaretin ve devletle olan işlemlerin sanal bir ortama taşınması (örneğin e-devlet uygulamaları), yaşanan gelişimlerin ne kadar hızı olduğunu göstermektedir. Verilen örneklerin toplumlar arasında yenilik olarak sürekli bir biçimde ortaya çıkması ve bu yeniliklerin iletişim kanalları vasıtası ile yüksek hızlarda yayılması farklı sonuçlar doğurabilir. Ayrıca, bahsedilen nedenlerden dolayı ülkelerin ortaya sürekli olarak çıkan yenilikleri takip etmeleri, kendilerini de yenilemeleri anlamına gelebilmektedir. Şüphesiz ki, internetin günlük yaşamda "yerleşik" bir hal alması da; iletişimin, ticaretin, uluslararası anlaşmaların, ekonomik ve kültürel örüntülerin boyutlarını sürekli olarak değiştirmektedir. Örneğin, ticaretin internet yoluyla yapılması, ülkelerarası sınırları kaldırmış ve bu sayede ekonomik anlamda yeni gelişmeler kendini göstermiştir. Bunlardan birincisi, dijital ağlar aracılığıyla gerçekleştirilen sanal ekonomidir. İkincisi ise 
yaratılan sanal ekonomi sayesinde yeni olarak nitelendirilecek çok sayıda ürünün çıkması, böylece tüketiciler ile üreticiler arasındaki mesafenin kısalmasıdır. Bu yolla, mekâna bağımlılık kavramı da gittikçe ortadan kalkmaktadır.

Yukarıdaki tartışmalar göz önünde bulundurulduğunda, bilginin taşıdığı rolün ve bilgiye olan ihtiyacın ne kadar büyük olduğu gözden kaçmamaktadır. Yukarıda belirtildiği gibi, yeni ekonominin oluşumunda bilgiye duyulan intiyacın önemli sonuçlarından biri, ülkelerin kendilerini ekonomik anlamda yeniden tanımlamasıdır. Ülkelerin oluşan yeni sektörlerde ne kadar çalışan istihdam ettiği, bu sektörlere yönelik ne kadar örgütün kurulması gerektiği, oluşabilecek her türlü maliyetin tespit edilmesi ve gerektiğinde en aza indirilmesi, bilgiye olan intiyacı gereksindirmekte rol oynamaktadır. Bu duruma yönelik olarak, klasik anlamda ekonomilerin temel aldıkları koşulların ne kadar güvenilir ve geçerli olabileceğinin tartışılabilir bir durum haline geldiğini söylemek mümkündür. Bilginin oluşan yeni ekonomi üzerinde etkin rol oynaması, "bilgiye dayalı ekonomi" kavramını ortaya çıkarmaktadır (Kim ve Mauborne, 1997, s.71; Porat, 1977; Arrow, 1984; Parker; 1988; Galatin ve Leiter, 1981; Burns, 1986). Bilginin bir "üretim faktörü" olarak tanımlanması ile bilginin yapısı ve sahip olduğu özellikleri gereği kolay ulaşılması, sürekli yenilenmesi, paylaşılması, paylaştıkça artması ve üstbilgiye dönüştürülmesi sürecinde oluşacak olan mübadelelerin ve maliyetlerin ekonomik olarak ele alınması, klasik ekonomi anlayışından farklılık göstermektedir. Diğer yandan bilgi ekonomisi, kendi alanında farklı konulara odaklanabilmektedir. Bu konularla ile ilgili örnekler olarak ekonomik ve kurumsal rejim, nüfus, enformasyon altyapısı ve inovasyon sistemini vermek mümkündür (Gürdal, 2004, s. 57).

Klasik ekonomiden farklılık gösteren bu yeni ekonominin özellikleri, (1) üretim yerine bilginin gücünün önemli ve maliyetlerin düşük olması; (2) örgütlerarası iletişimdeki sanallaşma; (3) örgüt bağlamında bireye ve insan sermayesine daha fazla önem verilmesi; (4) ülkelerin internet teknolojisi sayesinde birbirlerine "ağlarla" bağlanması ve (5) bu ağlar sayesinde yenilik takibinin kolaylaşması; (6) politik, ekonomik, kültürel gibi konularda ve güvenlik açısından farklı sorunların belirmesi biçimlerinde karşımıza çıkmaktadır. $\mathrm{Bu}$ özelliklerin yanısıra bilgiye dayalı ekonomi; avantajları ve dezavantajlarıyla da gündeme gelmektedir.

Yukarıda ele alınan tartışmalar doğrultusunda akla gelen ilk soru, bilgi ekonomisinin özelliklerini öne çıkarabilecek değişkenlerin neler olabileceği ve bu değişkenlerin sayısal olarak nasıl belirlenebileceğidir. Bu, aynı zamanda çalışmanın araştırma problemini de ortaya koymaktadır. Yapılan çalışmada sorunun çözümüne yönelik hangi yöntemin izleneceği önem kazanmaktadır. Çalışmanın bundan sonraki aşamalarında bir yazın taraması yapılmış, çeşitli yazarların bilgi ekonomisi değişkenlerini ne şekilde ele aldıkları ve nasıl ölçtükleri hakkında bilgiler verilmiştir. Bu bilgilere ek olarak, bilgi ekonomisine ait tespit edilen değişkenler, görgül olarak çok değişkenli istatistiksel yöntemlerle test edilmiştir. Böylece çalışmanın esas sorunsalına, eşdeyişle Türkiye'nin diğer ülkeler içinde ne şekilde konumlandırılabileceği yönündeki tartışmalara yönelik bulgular değerlendirilmiştir. 


\section{Yazın Taraması}

Bir önceki bölümde vurgulandığı üzere, bilgi ekonomisinin klasik ekonomiden en belirgin farklıı̆̆, ele aldığı değişkenlerin daha farklı oluşudur. Genel olarak klasik ekonomi; pazar koşulları, arz-talep dengeleri, gayrisafi milli hâsıla gibi mikro ve makro konulara ağırlık vermektedir. Bu konulara yönelik teoriler ve kavramların, kısmen de olsa bilindiği varsayılmaktadır. Ancak burada önemli olan, bilgi ekonomisinin değişkenlerinin ne olacağıdır.

Yazın taraması yapıldığında, farklı yazarların (örneğin Boon ve diğerleri, 1994; Madon, 1997; Kuo ve Low, 2001; Daveri, 2002; Matuschewski, 2006; Godin, 2008) uluslararası bağlamda bilgi ekonomisini farklı açıdan ele aldıkları ve değişkenleri farklı tanımlayarak değerlendirdikleri görülmektedir. Bununla birlikte söz konusu çalışmalardaki uygulanan araştırma yöntemi farklılıklara dikkat çekmektedir. Örneğin; Brooks ve diğerleri (2002, s.568), bilgi ekonomisinin ölçümünde üretici ve tüketici davranışlarını inceleyerek, bu davranışları modelleyebilme çabası içine girmişlerdir. Yazarlara göre, hem üretici hem de tüketici değerlerinin modellenmesi, onların kendi davranışları hakkında bilgi verebilmektedir. Bunlar birey olarak değil, bireylerin oluşturdukları topluluklar olarak düşünüldüğünde, toplam değerlerin modellenebileceği yönündeki tartışmalar da, yine aynı yazarlarca ele alınmıştır. Diğer yandan bu yazarlar, tekelci piyasa koşullarını göz önünde bulundurarak fiyatları modellemişlerdir. Ele alınan modellerde temel varsayım, fiyatların "durağanlık" göstermediği, bu yüzden zaman içinde fiyatlarda gözlemlenen artan ya da azalan yöndeki değişimlerin, yine hem üretici hem de tüketici davranışları üzerinde olumlu ve olumsuz yönde etkili olabileceğidir.

Susman ve Santos (2002, s.429), çalışmalarında Amerika'da yaşanan değişimlerin Amerikan ekonomisini derinden etkilediğini belirtmişlerdir. Yazarlara göre, sanayiye dayalı bir üretim ekonomisi ağırlığını gittikçe yitirmiş ve yerini insan ve teknolojiye dayalı dinamiklere bırakmıştır. İnsan sermayesinin ve teknolojinin sürekli artış göstermesi ve büyümesi, yeni intiyaçların da doğmasına neden olmuştur. Bu bakımdan, bilgiye dayalı yatırımların önemi bir kez daha öne çıkmıştır. Bu yatırımların temel amacı "etkililiği" ve "etkinliği" artırmaya yönelik olup, bu bağlamda hem gelişim hızını artırmak hem de refah seviyesini varolan düzeyinden daha yukarıya taşımaktır. Yazarlar, bu amaç doğrultusunda bilgi teknolojilerine dayalı yatırımların önemli olduğunu ve bunun için yapılacak yatırımların yeniden düzenlenmesi gerektiğini savunmuşlardır.

Kim ve diğerleri (2002, s.215), bilgi ve sayısal ekonomide var olan ve halen kullanılmakta olan "eski" yöntemlerin önemli olmalarına karşın, yeni yöntemlerin de sürekli gelişmekte olduğuna dikkati çekmektedirler. Yazarlar, gelişmekte olan yeni yöntemlerden biri olan "sanal alan deneyi"ni kendi çalışma kapsamlarına almışlardır. Bu yöntem sayesinde değişkenlerin birbirleriyle olan çoklu ilişkilerinin daha net bir şekilde ele alınabileceğini göstermişler ve deneysel kontrolün, geçerliliklerin, tahminleme güçlerinin yüksek olduğunu belirtmişlerdir. Ancak yapılan araştırmaların uzun zaman içerdiğini ve teknik altyapının oldukça önemli yatırımlara sahip olması gerektiği konusunu dile getirmişlerdir. Ayrıca sayısal ekonominin sağladığı avantajlara da yer verilmiştir. Bunlar; a) bilgiye ulaşımdaki kolaylık, b) değişkenlerarası etkileşimlerin zenginliği ve c) bilgi ve etkileşim maliyetlerinin düşük olması olarak sıralanmaktadır. 
Harrison ve Leitch (2002, ss.109-111), bilgi ekonomisinin değerlendirilmesini bireyden örgüt düzeyine taşımışlardır. Yazarlara göre, örgütlerin strateji geliştirmeleri, politik süreçleri katılımcı yaklaşımlarla gerçekleştirmeleri, yeni gelişmelerle ilgili olarak sürekli bilgilenmeleri ve öğrenmeleri, pazarda oluşan yeni durumlar açısından önemlidir. Pazarda ekonomik açıdan meydana gelebilecek ani bir değişim (örneğin finansal bir şok) bir bilgi intiyacını doğurabilir. Örgütün bu bilgi intiyacını karşılaması için varolan kaynaklarını geliştirmesi gerekmektedir. Böylesine gereksinimler örgütlerin bilgiye ulaşma gayretlerini artıracak ve çevresel tarama yöntemi ile gereksinim duyulan verilerin toplanmasına yol açacaktır.

Pau (2002, s.1651), iletişim ve bilgi ekonomisiüzerinde yoğunlaşmış, bilgi ekonomisinin ve bilgi sektörünün birçok değişkenden oluşması gerektiğini ortaya koymuştur. Yazar, bu değişkenleri, a) iletişim altyapısı ve tariflendirme ilkeleri, b) iletişim hizmetlerinin satışları, c) ulaşım ve eşitlik ilkeleri, d) rekabetçi fiyatlandırma, e) iletişim sektörünün finansmanı, f) makroekonomik konular olarak tanımlamıştır. Yazarın çalışmasında yaptığı önemli vurgulardan biri de, aktörlerin önemi ile ilgilidir. Yazara göre, ekonomiye ait hiçbir sorun aktörden bağımsız değildir ve aktörlerin niteliği ekonomileri yakından ilgilendirir (Pau, 2002, s.1653). Aktörler olarak tanımlanan müşteriler, operatörler, tedarikçiler, medya sahipleri, servis sağlayıcıları, düzenleyici yapılar ve hükümet yatırımları birer ekonomik gösterge olarak ele alınabilir. Bu durumun makroekonomik açıdan izlenmesi ise önemlidir.

Pau'nun yaklaşımlarına ek olarak, Bonatti, Ermoliev ve Gaivoronski (1998, s.93), pazarda bulunan aktörlerin birbirleriyle olan ilişkisinin açıklanabilir olduğunu belirtmektedirler. Pazarda oluşan fiyat koşulları her zaman değişebilmekte ve bir denge noktası her zaman bulunamamaktadır. Bu durumda, aktörlerin birbirleri ile olan dolaylı veya doğrudan etkileşimleri, sürekli olarak dinamik bir hal almaktadır. Yazarların tartıştığı ve ele aldığı konu, bu dinamik yapının modellenip modellenemeyeceğine yöneliktir. Yazarların modelleme konusunda ele aldığı kısıtlar, durağan olmama, belirsizlik, karmaşıklık, sınırlı rasyonellik değişkenliği olup, bu etkileşimler açısından anlamlı görülmektedir.

Lamberton (1998, s.338), bilgi ekonomisinin araştırılması ve ölçülmesindeki stratejiler üzerinde durmuştur. Yazar, bilgi ekonomisi değişkenlerine yönelik birincil ve ikincil verinin rahatlıkla bulunabileceğini, ancak bunlardan çıkabilecek sonuçların neler olabileceğinin daha dikkatli bir şekilde ele alınması gerektiğini savunmuştur. Örneğin, bilgi ekonomisinin ölçülmesinde bilgiyi oluşturabilecek alt değişkenlerin yeterli olarak tanımlanmadığı, bilgi teknolojilerinin baskın olabilecek esas rolünün ne olduğunun bilinmediği, yapılan ölçümlerde hata payının yüksek olduğu, yine yazar tarafından bir eleştiri olarak ifade edilmiştir (Lamberton, 1998, s.344).

Yazın taramasında görgül çalışmalar da incelenmiştir. Bu bulgular, çalışmamızda ele alınan temel problematiğin çözümüne yönelik olduğundan, izlenmiş olanı yöntembilim yaklaşımlarının irdelenmesinde fayda bulunmaktadır. Suriya (1998) çalışmasında, bilgi altyapısının nasıl ölçebileceğini, ülkelerde yarattığı farklılıkları ve insan kaynağındaki gelişimini ele almıştır. Yazar, bilgi altyapısının ölçülmesine yönelik olarak, ülkeleri beş farklı grupta toplamıştır: a) radyo iletişim sektörü, b) telekomünikasyon sektörü, c) bilgi teknolojileri alt yapısı ve servis sektörü, d) bilgi dağıtım sektörü ve e) bilgi üretim sektörüdür (Suriya, 1998, s.153). Yazar, bu değişkenleri kullanarak yaptığı 
analizlerde, gelişmiş ülkelerde bilgi altyapısına yapılan yatırım miktarının oldukça yüksek olduğunu ve bu nedene bağlı olarak insan kaynağına daha fazla gereksinim olduğunu vurgulamıştır. Gelişmiş olan ülkelerin yanısıra, "gelişmekte" olan ülkelerde ise insan kaynağının yetersiz olduğu ve insan sermayesine yapılacak olan yatırımların bu ülkeler açısından fayda sağlayacağı yine bu yazar tarafından savunulmuştur.

Mannisto ve Kelly (1999, ss.299-300), Suriya'nın (1998) çalışmasında olduğu gibi bir gruplama yapmaktan ziyade istatistiksel çıkarımlara yönelmişlerdir. Ayrıca, ülkeler arasında çoklu bir karşılaştırma yapmışlar ve çıkan sonuçları irdelemişlerdir. Yazarlar a) kullanılan bilgisayar sayısını, b) bilgisayar yoğunluğunu, c) İnternet servis sağlayıcılarını, d) İnternet servis sağlayıcıları yoğunluğunu değişkenler olarak ele almışlar ve ülkeleri bu değişkenler itibariyle karşılaştırmışlardır. Değişkenlere göre yapılan analizlerde, Türkiye'ye ait sonuçlar da vardır. Elde edilen bulgulara göre Türkiye, 1998 yılı itibariyle \%2,07'lik bilgisayar yoğunluğuna, \%7,00'lik internet sağlayıcısı yoğunluğuna sahiptir.

Karunaratne (2001), bilgi sektörünün altyapısını ölçmeye çalışmış, bunun için "girdiçıktı" analizini uygulamış ve yayınlanmış olan OECD istatistiklerini temel almıştır. Yazar, analizlerinde a) farklı sektörlerdeki satış miktarlarını, b) talepleri ve arzları, c) katma değerleri ve gelirleri değişken olarak almıştır. Godin (2004), Karunaratne (2001) gibi OECD verilerini kullanan diğer bir yazardır (Godin, 2004, s.599).

Yukarıda ele alınan yazarların tüm önermeleri, varsayımları ve tanımladıkları değişkenler dikkate alındığında; bu çalışmanın yönünün belirlenmesi için bilgi ekonomisinin "kriterleri" olabilecek değişkenler ortaya çıkmaktadır. Aşağıda, bu çalışmaya özgü varsayımlar ve gerekçeler detaylı olarak tartışılmıştır.

\section{Değişkenlerin Belirlenmesi ve İzlenecek Yöntemlerin Tartışılması}

Giriş kısmında belirtildiği gibi önemli olan, değişkenlerin nasıl belirleneceği ve Türkiye'nin bu değişkenlerin yardımı ile diğer ülkeler arasında nasıl konumlandırılacağıdır. Burada önemli olan Türkiye'nin diğer ülkeler arasındaki sırası değil, hangi ülkeler ile benzer özellikler gösterdiğinin belirlenmesidir. Bu, yeni bir yaklaşımdır ve umarız ki, ileride yapılacak olan diğer çalışmalara da yön gösterebilecektir.

Çalışmada kullanılacak verilerin kaynaklarının belirlenmesinde farklı yollara başvurulmuştur. Yukarıda belirtilen yazın taramasının sunduğu olanakların ötesinde birçok birincil ve ikincil kaynağa ulaşılmıştır. Örneğin, konu ile ilgili çok sayıda site ziyaret edilmiş ve birçok kitap değerlendirilmiştir. Verilerin elde ediniminde yapılan görgül çalışmaların katkısı büyüktür. Örneğin, Karunaratne (2001) ve Godin (2004)'in çalışmaları, bu araştırma için ayrıntılı fikirler sağlamıştır.

\section{Çalışmanın Kısıtları}

Çalışmanın kısıtlarından biri, temel alınan konu hakkında geçmiş verilerden yararlanılmasıdır. 1995 - 1999 yılları arasındaki veriler ikincil kaynak olarak kullanımında güvenirliğin yüksek olması nedeniyle tercih edilmiştir. 
Diğer bir kısıt ise, yazında bilgi ekonomisini oluşturan değişkenlerin neler olduğu konusundaki bulanıklıktır. Özellikle bilişim ve teknoloji sektörüne ait değişkenlerin finansal olarak tanımlanmasındaki güçlük ve insan sermayesinin ölçülmesindeki zorluklar nedeni ile yazında, bu değişkenleri tanımlayabilmek bakımından güçlükler yaşanmaktadır. Bu bakımdan araştırmada kullanılması yeğlenen değişkenler, aşağıda belirtilmiştir.

Çalışmada, OECD ülkelerine ait varolan veriler üzerinden analizler yapılmış, verilerine ulaşılamayan ülke kapsam dışı bırakılmıştır.

\section{Değişkenlerin Belirlenmesi}

İlk aşamada bilgi ekonomisinin ölçülmesi için ele alınan değişkenlerin belirlenmesine yönelik OECD'nin web sitesi ${ }^{* * *}$ ziyaret edilmiştir. Bu sitedeki istatistiklerde ülkelerin bilgi ve iletişim teknolojilerine ait birçok zaman serisine erişilebilir. Bilgi ekonomisi değişkenlerinin belirlenmesinde, OECD'nin yayınladığı "OECD Communications Outlook, 2003” adlı rapor da önemli rol oynamaktadır. Ayrıca, aynı sitede bulunan bilgi ekonomisi değişkenlerinin neler olabileceğine dair farklı istatistiksel verilere ulaşmak mümkündür.

Çalışmada OECD tarafından bilgi ekonomisinin ölçümüne yönelik değişkenleri ele alırken, farklı ülkeler incelenmiştir. OECD ülkeleri olan Avusturya, Avustralya, Belçika, Danimarka, Kanada, Çek Cumhuriyeti, Danimarka, Finlandiya, Fransa, Almanya, Macaristan, İzlanda, İtalya, Japonya, Kore, Meksika, Hollanda, Yeni Zelanda, Norveç, İspanya, Portekiz, İsveç, İsviçre, Türkiye ve ABD verilerini, kendi İnternet sitelerinde bulundurmaktadır.

OECD'nin raporlarında bilgi ekonomisinin ölçümünde hepsi teknoloji ve bilişim sektörlerine ait üretim, katma değer, istihdam, ücretler ve ödenen maaşlar, kurulan örgüt sayısı değişken olarak yer almaktadır.

Ele alınan değişkenlere özgü sayısal değerler, şu şekilde formüle edilerek hesaplanmıştır.

Üretim $=\Sigma$ (Yılbaşındaki çıktının değeri $)-\Sigma($ Yılsonundaki satış ve servislerden elde edilen hasılat miktarı + Sabit varılıkların üretim değeri)

Katma Değer $=\Sigma(C ̧ ı k t ı)-\Sigma($ Girdi $)$

$\Sigma$ Girdi $=($ Yılsonu stok miktarının finansal değeri $)-($ Yeni yılda üretilip stokta bulunan mal ve hizmetlerin üretim ve transferdeğeri + üretilen elektriğin finansal değeri )

İstihdam = (Yılsonundaki o sektörde çalışan insan sayısı $)$

Ücretler ve Maaşlar $=($ Brüt maaşlar $)+($ Primler $)+($ Fazla mesai ücretleri $)+$ (Diğer ek gelirler)

Kurulan Örgüt Sayısı = (Yılsonunda o sektörde bulunan örgüt sayısı)

\footnotetext{
*** OECD'nin İnternet sitesine www.oecd.org adresinden ulaşılabilir.
} 
Ülkelere ait, bilgi ekonomisi değişkenleri itibariyle yapılan ölçümler, bazı nedenlerden dolayı birbirinden farklılık göstermektedir. Bunlardan birincisi, verilerin ait olduğu dönemde her ülkenin para biriminin birbirinden farklı oluşudur. Bu farklılık, analizlerin yapılmasında yanlış sonuçlar vereceğinden, ülkeler Ortak Para Birimine (European Currency Unit) geçmiştir. Bu dönüşüm sayesinde para birimleri standartlaştırılmıştır. Dönüşüm formülü şöyledir:

Miktar $_{\text {ECU }}=$ Miktar X (Ülke para birimi / ECU para birimi)

Daha sonraki aşama, ülkelerin birbirleri ile olan benzerlik ve farklılıklarının saptanmasını içermektedir ve bunlar aşağıda açıklanacağı şekilde gerçekleştirilmiştir:

Ülkelerin verilerine bakıldığında, en sağlıklı verinin 1995 ve 1999 yıllarına ait olduğu tespit edilmiş ve ilgili tüm analizler bu yıllara göre yapılmıştır. Bir ülkenin gösterdiği değişim, diğer bir ülkenin gösterdiği değişime göre farklılık ortaya koyabilir. Bu bakımdan, benzerlik ve farkıııkların ele alınması için her ülkenin bu yıllar içinde yaşadığı değişimin yüzdesi şöyle hesaplanmıştır.

\section{\%Değişim = $\left(\right.$ Son $\left.Y_{\mathrm{I}} / \mathrm{IIlk} \mathrm{Y}_{\mathrm{I}}\right)-1$}

Bu değişim formülünden yola çıkarak, bilgi ekonomisi değişkenlerinin ayrı ayrı yüzde (\%) değişim tabloları elde edilmiştir. Hem para birimi, hem de yüzde değişim açısından hesaplanan verilerin analizini yapmak daha uygundur.

Çalışmada yüzde değişimlerinde gözlemlenen benzerliklerin tespiti için "hiyerarşik kümeleme analizi" yöntemi kullanılmıştır. Hiyerarşik kümeleme analizinin amacı, değişkenleri, birbirlerine olan analitik uzaklıklarına göre belirli kümeler altında toplamaktır. Bu analiz sayesinde elde edilen veriler ile geleceğe yönelik kestirimler yapılamamakta, anlık durumu gösterdiği için durum hakkında bir fikir sahibi olunmaktadır. İzlendiği üzere, bir küme içerisinde bulunan değişkenlerin birbirleriyle olan ilişkileri, diğer kümelerde olan değişkenlerin ilişkilerinden daha yüksektir. Bu bir bakıma, küme içinde bulunan değişkenlerin kendi içlerinde homojen, kendi aralarında heterojen bir yapı sergilediğini göstermektedir. Çalışma tarafından ele alınan değişkenler ile kümeleme analizinin sonuçları aşağıdaki gibidir. İzleme kolaylığını sağlamak açısından veriler tablolar halinde verilmiş, mevcut durum dendogramlarda gösterilmiştir.

\section{Analiz Sonuçları}

Tablo 1'de ülkelerin bilgi ve iletişim teknolojilerine ait 1995-1999 yılları arasındaki üretim miktarlarına ilişkin değişim yüzdeleri verilmektedir. Tablo 1'e göre, üretim miktarındaki en büyük artışı Finlandiya gösterirken, en düşük artışı \%0,03'lük yüzde ile Japonya'dadır. Türkiye'de ise, \%45'lik bir üretim artışı gözlemlenmiştir. İspanya, Fransa ve Hollanda birbirlerine yakın olmasına rağmen, Belçika bu ülkelere göre daha az gelişme sergilemektedir. Bu değişimlere ait kümeleme analizi sonuçları ise, Şekil 1'deki gibidir. Üretim miktarlarına yönelik değişimleri gösteren tabloda; ABD, Almanya, Avustralya'ya ait verilerin olmayışı, İtalya ve Portekiz'e ait kısmi (sadece 1999 yılına ait) verilerin bulunması nedeniyle kümeleme analizine bu ülkeler dahil edilmemiştir. Bu verilere ait dendogram Şekil 1'deki gibidir. 
Tablo 1. Üretim Miktarlarına (Milyon ECU) Yönelik Değişim Yüzdeleri

\begin{tabular}{|l|c|c|c|}
\hline \multicolumn{1}{|c|}{ Ülkeler } & 1995 Yılı & 1999 Yılı & Değişim (\%) \\
\hline ABD &. &. &. \\
\hline Almanya &. &. &. \\
\hline Avustralya &. &. &. \\
\hline Belçika & 4571,00 & 4994,00 & 09 \\
\hline Danimarka & 2611,00 & 3488,00 & 34 \\
\hline Finlandiya & 6689,00 & 17609,00 & 163 \\
\hline Fransa & 52711,00 & 66301,00 & 26 \\
\hline Hollanda & 12481,00 & 15506,00 & 24 \\
\hline İngiltere & 49421,00 & 96502,00 & 95 \\
\hline İspanya & 10328,00 & 12574,00 & 22 \\
\hline İsveç & 12069,00 & 23702,00 & 96 \\
\hline İtalya &. & 24738,00 &. \\
\hline Japonya & 429838,00 & 441255,00 & 03 \\
\hline Kanada & 20075536,0 & 26356449,00 & 31 \\
\hline Norveç & 1780,00 & 2850,00 & 60 \\
\hline Portekiz &. & 3288,00 &. \\
\hline Türkiye & 2118,00 & 3072,00 & 45 \\
\hline
\end{tabular}

Şekil 12deki dendogram, yüzde değişimlere göre ülkelerin kümelerini göstermektedir. Genel olarak bakıldığında dendogram, iki ana kümeye işaret etmektedir. Birinci ana küme, İngiltere, İsveç ve Finlandiya, ikinci ana küme ise diğer ülkelerden oluşmaktadır. İkinci ana kümede bulunan alt kümelere bakıldığında, Türkiye ve Norveç'in aynı kümede olduğu, Japonya, Belçika ve Kanada'nın ise, Danimarka, Fransa, İspanya ve Hollanda ile benzerlik gösterdiğinden kendi aralarında bir alt küme oluşturduğu izlenmektedir.

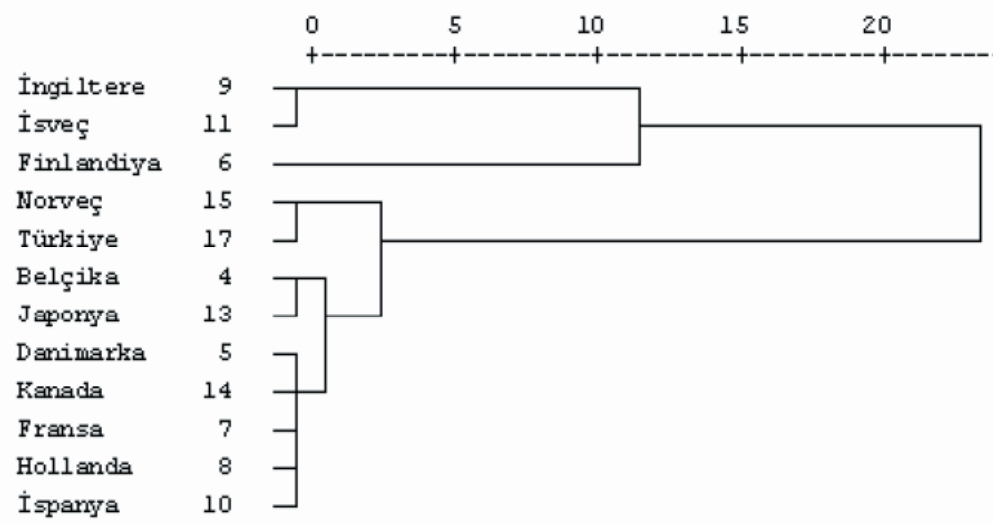

Şekil 1. Ülkelerin Gösterdiği Değişimlere Göre Oluşturdukları Kümelere Ait Dendogram 
Tablo 2'de ise, bilgi ekonomisini ölçmede kullanılan katma değer değişkenine ait hesaplanan değişim yüzdeleri bulunmaktadır. Daha önce bahsedildiği gibi, katma değer değişkeninin alt değişkeni olarak "bilgisayar ve ilgili aktiviteler" kısmı alınmıştır. Tablo 2 incelendiğinde; Almanya, Avustralya, İspanya, İtalya, Norveç ve Portekiz'e ait tek bir yıl verisi bulunduğundan yüzde değişimleri hesaplanamamıştır. Tabloya göre; $A B D$, Hollanda, İngiltere, Kanada ve İsveç'in \%100'ün üzerinde bir değişim gösterdiği, en büyük değişimi ise \%336'lık büyüme ile Türkiye'nin gerçekleştirdiği gözlemlenmektedir. Dolayısıyla bu benzer büyümelerin bir küme içinde birleşeceği beklentisini karşılamak amacıyla kümeleme analizini kullanarak bir dendogram çizilmiştir. Şekil 2'de gösterilen bilgisayar ve ilgili aktivitelere yönelik değişim yüzdelerine ait dendogram, olguyu daha net açıklamaktadır.

Tablo 2. Bilgisayar ve İlgili Aktivitelere (Milyon ECU) Yönelik Değişim Yüzdeleri

\begin{tabular}{|l|l|l|l|}
\hline Ülkeler & 1995 Yılı & 1999 Yıll & Değișim \% \\
\hline ABD & 81644 & 205484 & 152 \\
\hline Almanya &. & 27229 &. \\
\hline Avustralya & & 5504 &. \\
\hline Belcika & 2910 & 3744 & 29 \\
\hline Danimarka & 1643 & 2645 & 61 \\
\hline Finlandiya & 766 & 1478 & 93 \\
\hline Fransa & 10045 & 17304 & 72 \\
\hline Hollanda & 2660 & 6335 & 138 \\
\hline Inqiltere & 9389 & 22486 & 139 \\
\hline İspanya &. & 3599 &. \\
\hline İsvec & 2023 & 4821 & 138 \\
\hline Italya &. & 10079 &. \\
\hline Japonya & 23689 & 39820 & 68 \\
\hline Kanada & 3193485 & 7097649 & 122 \\
\hline Norvec &. & 15826 &. \\
\hline Portekiz &. & 595 &. \\
\hline Türkiye & 26975 & 117659 & 336 \\
\hline
\end{tabular}

Şekil 2'deki dendograma göre Türkiye, gösterdiği büyüme açısından tek bir küme olarak kendini temsil etmektedir. Diğer ana küme iki alt kümeye ayrılmıştır. Birinci alt kümeyi; Hollanda, İsveç, İngiltere, ABD ve Kanada; ikinci alt kümeyi ise Fransa, Japonya, Danimarka, Finlandiya ve Belçika oluşturmaktadır. Avrupa ülkelerinin benzer kümelerde olması, ABD ve Kanada'nın benzer özellikler göstermesi dikkat çekicidir. Ayrıca, 1995 yılından 1999 yılına gelişimin bu değişkene göre oldukça hızlı olması tespit edilen diğer bir bulgudur. 


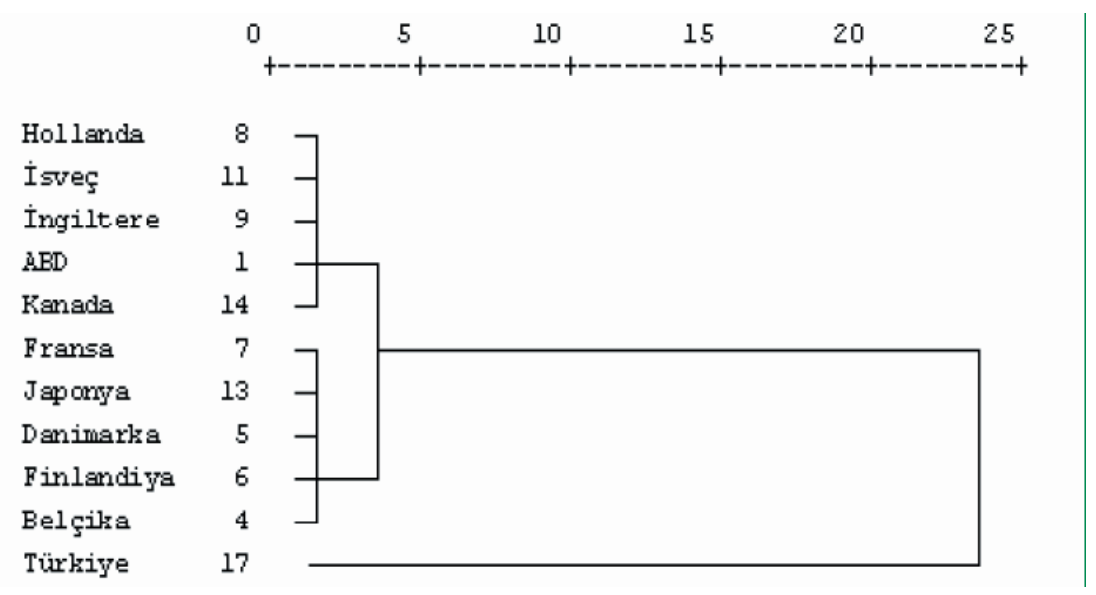

Şekil 2. Ülkelerin Gösterdiği Değişimlere Göre Oluşturdukları Kümelere Ait Dendogram

Bir sonraki tablo (Tablo 3), ülkelerde istihdam edilen bireylerin yıllara göre yüzde değişimlerini göstermektedir. Değişimler hesaplandığında, Türkiye'nin \%45'lik bir artış gösterdiği ve Norveç, İsveç ve Japonya ile benzer yüzde değişimlerinde yer aldığı görülmektedir. Tablo'da Avusturya'nın durumu dikkat çekmektedir. Bu ülkenin istihdam seviyesindeki değişim negatif yöndedir. Bu durum bir dendogram ile ifade edildiğinde, Avusturya'nın tek başına bir küme olacağı açıktır. Diğer ülkelere bakıldığında ise pozitif yönde en az büyüyen ülkenin Belçika olduğu tespit edilmiştir.

Tablo 3. İstihdama Göre Değişim Yüzdeleri

\begin{tabular}{|l|c|c|c|}
\hline \multicolumn{1}{|c|}{ Ülkeler } & $\mathbf{1 9 9 5}$ & $\mathbf{1 9 9 9}$ & Değişim \% \\
\hline ABD & 8277200 & 10713900 & 29 \\
\hline Almanya &. & 1029746 &. \\
\hline Avusturya & 306880 & 260097 & -15 \\
\hline Belçika & 231051 & 249786 & 8 \\
\hline Danimarka & 189317 & 250810 & 32 \\
\hline Finlandiya & 165205 & 229113 & 39 \\
\hline Fransa & 1453015 & 1801197 & 24 \\
\hline Hollanda & 390000 & 519000 & 33 \\
\hline İngiltere & 2085 & 3052 & 46 \\
\hline İspanya &. & &. \\
\hline İsveç & 327790 & 466013 & 42 \\
\hline İtalya &. & 1474761 &. \\
\hline Japonya & 1469546 & 2087885 & 42 \\
\hline Kanada & 811717 & 969110 & 19 \\
\hline Norveç & 126427 & 182000 & 44 \\
\hline Portekiz &. & 202474 &. \\
\hline Türkiye & 22876 & 33137 & 45 \\
\hline
\end{tabular}


Tablo 4, bilgi ve iletişim teknolojileri sektöründe çalışan bireylere ödenen ücretlerde hesaplanan yüzde değişimlerini vermektedir. Tabloya bakıldığında, Kanada'nın istihdam konusunda çok ciddi bir artış yaşadığı, İngiltere ve İsveç'in \%100'ün üzerinde bir gelişim gösterdiği; Türkiye'de ise beş yılda sadece \%17'lik bir artış olduğu dikkati çekmektedir. Diğer yandan Danimarka ile Finlandiya benzer değişimler göstererek aynı kümeye girmiş, benzer bir artış da Fransa'da izlenmiştir. Benzerlikler Şekil 3'te yansıtılmıştır. Dendograma göre Norveç'in tek başına bir ana küme olduğu ve İspanya'nın diğer ana küme içerisinde yer aldığı görülmektedir. Ancak genel olarak bakıldığında, 1999 yılında referans yılı olan 1995'e göre anlamlı artışlar bulunmuştur. Buradan, çalışan sayılarının artması ile birlikte çalışanlara ödenen ücretlerin de artığını söylemek mümkündür. Ayrıca bu, bilgi ekonomisindeki geçişin ne kadar hızlı olduğunun da bir göstergesidir.

Tablo 4. Çalışanlara Ödenen Ücretlerdeki Yüzde Değişim

\begin{tabular}{|l|c|c|c|}
\hline \multicolumn{1}{|c|}{ Ülkeler } & 1995 Yılı & 1999 Yılı & Değişim \% \\
\hline ABD &. &. &. \\
\hline Almanya &. &. &. \\
\hline Avusturya & 16286 & 23726 & 46 \\
\hline Belçika & & 27407 & \\
\hline Danimarka & 28007 & 35970 & 28 \\
\hline Finlandiya & 11848 & 14924 & 26 \\
\hline Fransa & 98467 & 115971 & 18 \\
\hline Hollanda &. & &. \\
\hline İngiltere & 129038 & 376801 & 192 \\
\hline İspanya & 1467 & 9200 & 527 \\
\hline İsveç & 25793 & 68274 & 165 \\
\hline İtalya &. & 235699 & \\
\hline Japonya & 26679 & 42310 & 59 \\
\hline Kanada & 23608 & 113018 & 379 \\
\hline Norveç & 115 & 21553 & 1860 \\
\hline Portekiz & & 16287 & \\
\hline Türkiye & 419 & 492 & 17 \\
\hline
\end{tabular}




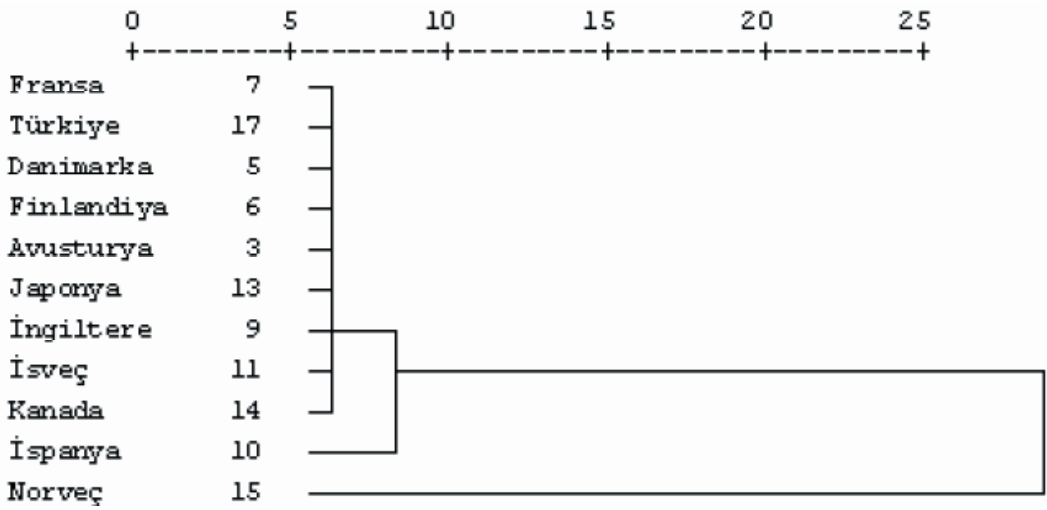

Şekil 3. Çalışanlara Ödenen Ücretlerdeki yüzde değişime Ait Dendogram

Ele alınan son değişken, kurulan örgüt sayılarına ait değişimleri ifade etmektedir (Bkz. Tablo 5). Tablo 5 ile Şekil 4'te bulunan dendogramdan görüldüğü üzere, Avrupa ülkelerinin benzer kümelerde, $A B D$ ve İngiltere gibi gelişmiş ülkelerin ise ayrı benzer kümelerde toplanmıştır. Batı Avrupa ülkelerinin aynı kümelerde toplanması dikkati çeken başka bir bulgudur. Türkiye'de ise bilişim ve iletişim teknolojileri sektöründe kurulan örgüt bakımından diğer ülkelere göre negatif yönde bir gelişim izlenmiştir.

Tablo 5. Ülkelerde Kurulan Örgüt Sayılarındaki Yüzde Değişim

\begin{tabular}{|l|c|c|c|}
\hline \multicolumn{1}{|c|}{ Ülkeler } & 1995 Yılı & 1999 Yılı & Değişim \% \\
\hline ABD & 301864 & 677310 & 124 \\
\hline Almanya &. &. &. \\
\hline Avustralya &. &. &. \\
\hline Belçika & 14114 & 15461 & 1 \\
\hline Danimarka & 8957 & 11150 & 24 \\
\hline Finlandiya & 4910 & 8664 & 76 \\
\hline Fransa & 39486 & 56438 & 43 \\
\hline Hollanda & 14016 & 20837 & 49 \\
\hline İngiltere & 45324,85 & 106010 & 134 \\
\hline İspanya & 1602 & 1831 & 14 \\
\hline İsveç & 9040 & 17042 & 89 \\
\hline İtalya &. &. &. \\
\hline Japonya & 82071 & 100720 & 23 \\
\hline Kanada & 19934875 & 33970415 & 7 \\
\hline Norveç & 5191 & 9149 & 76 \\
\hline Portekiz &. & 3288 &. \\
\hline Türkiye & 674 & 632 & -6 \\
\hline & & &
\end{tabular}


Şekil 4'teki dendograma göre, ABD ve İngiltere bir ana küme; diğer ülkeler ise ayrı bir ana küme olarak ayrılmıştır. İkinci ana küme ise iki alt ana kümeye ayrılmıştır. Türkiye ikinci alt kümede tek başına yer almaktadır. Bu durum daha önceden bahsedildiği gibi negatif yönlü gelişimden kaynaklanmaktadır.

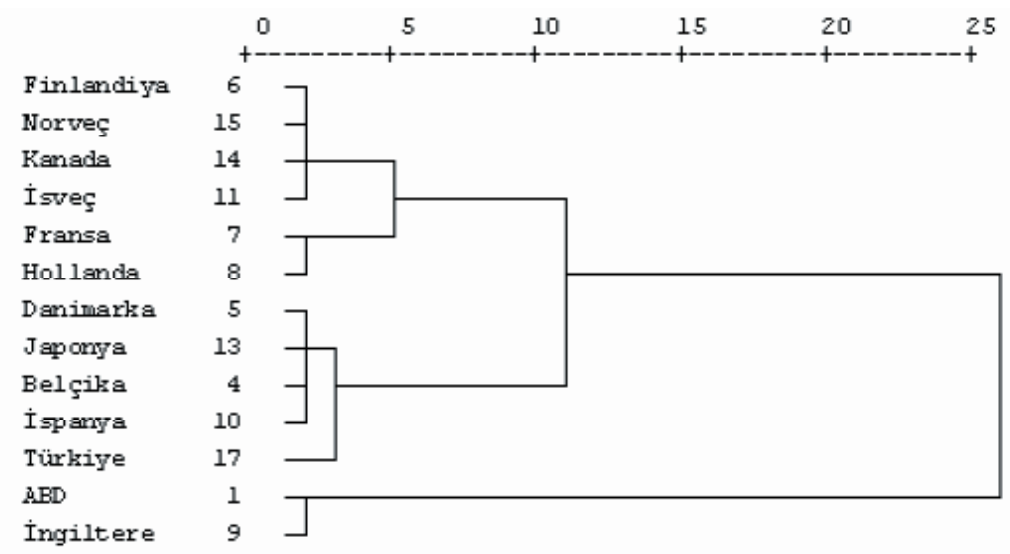

Şekil 4. Ülkelerde Kurulan Örgüt Sayılarındaki Yüzde Değişime Ait Dendogram

\section{Sonuç ve Geleceğe Yönelik Çalışmalar}

$\mathrm{Bu}$ çalışmada öncelikle bilgi ekonomisinin değişkenlerine ilişkin yazından hareketle beş değişken belirlenmiştir: 1) Üretim, 2) Katma değer, 3) İstihdam, 4) Ücretler ve ödenen maaşlar, 5) Kurulan örgüt sayısıdır. Bu beş değişken dikkate alınarak Türkiye'nin OECD ülkeleri içerisindeki yeri konumlandırılmaya çalışılmıştır. Tablo ve şekillerden anlaşıldığı üzere, gelişmiş ülkelerin çoğunlukla benzer kümelerde toplandığı, Avrupa ülkelerinin ise bölgeler itibarıyla benzer değişimler gösterdiği anlaşılmaktadır. Türkiye'nin ise, bilgi ekonomisinin değişkenleri göz önünde bulundurularak OECD ülkeleri ile bir kıyaslama yapıldığında, daha çok Kuzey Avrupa ülkeleri ile benzer değişimler gösterdiği dikkat çekmektedir. Elde edilen bulgulardan hareketle, ülkemizin gelişmekte olan bir ülke olarak gelişme düzeyinin, bilgi ekonomisi değişkenleri göz önüne alındığında, OECD ülkelerine göre daha yavaş olduğu söylenebilir.

Her ne kadar bu durum istatistiksel olarak yavaş gibi görünse de, Türkiye'yi kendi dinamikleri çerçevesinde ele aldığımızda, ülkemizin bu konuda hatırı sayılır bir aşama kaydettiği ortaya çıkmaktadır. Özellikle Devlet Planlama Teşkilatı tarafından Temmuz 2006'da yayınlanan "Bilgi Toplumu Stratejisi 2006-2010" adlı rapordaki istatistiklerde de, bu gelişme odağına dikkat çekilmektedir.

Çalışmanın kavramsal çerçevesi doğrultusunda aşağıdaki hususlar göz önünde bulundurularak geleceğe yönelik yeni çalışmalar yapılabilir. Bunlar şu şekilde özetlenebilir: 
1. Bilgi ekonomisine yönelik herbir değişkenin birbirleri ile olan ilişkileri ve etki durumları incelenebilir. Örneğin; "çalışan sayısını hangi faktörler etkiler?" sorusu şu şekilde bir fonksiyon olarak yazıldığında;

Çalışan sayısı = $\mathrm{f}$ (maaşlar ve ücretler, kurulan örgüt sayısı, üretim, katma değer)

bu fonksiyon doğrusal bir modelle ifade edilebilir. Burada, çalışan sayısı bağımlı, diğer değişkenler ise bağımsız değişkenlerdir.

2. Görgül olarak çalışmanın kapsamı, 1995-1999 yılları arasını kapsamaktadır. Bu süreç 1999-2009 yılları dikkate alınarak genişletilebilir ve analizler yeniden yapılabilir. Hatta 1995-1999 ile 1999-2009 yılları arasında ortaya çıkan bulgular kıyaslanarak, Türkiye'nin OECD ülkeleri içerisindeki konumunun hangi yönlerde değiştiği ortaya konulabilir.

\section{Kaynakça}

Arrow, K. J. (1984). The economics of information. Cambridge, MA: Harvard University Press.

Bonatti, M., Ermoliev, M. Y. ve Gaivoronski, A. A. (1998). Modeling of multi-agent market systems in the presence of uncertainty: The case of information economy. Robotics and Autonomous Systems, 24, 93-113.

Boon, J. A., Britz, J. J., ve Harmse, C. (1994). The information economy in South Africa: Definition and measurement. Journal of Information Science, 20(5), 334-347.

Brooks, H. ve Gazale, S. R. (2002). Model Selection in an information economy: Choosing what to learn. Computational Intelligence, 18(4), 566-582.

Burns, C. (1986). The economics of information. Washington, DC: Office of Technology Assessment, US Congress.

Daveri, F. (2002). The new economy in Europe, 1992-2001. Oxford Review of Economic Policy, $18,345-362$.

Devlet Planlama Teşkilatı (DPT) (2006). Bilgi toplumu stratejisi: 2006-2010. Ankara: DPT.

Eddie, C. Y.; Kuo, E. C. Y ve Low, L. (2001). Information economy and changing occupational structure in Singapore. The Information Society: An International Journal, 17(4), 281-293.

Galatin, M. ve Leiter, R. D. (Der.) (1981). Economics of information. Boston: Nijhoff.

Godin, B. (2004). The new economy: What the concept owes to the OECD. Research Policy, 33, 679-690.

Godin, B. (2008). The information economy: The history of a concept through its measurement, 1949-2005. History and Technology: An International Journal, 24(3), 255-287.

Gürdal, O. (2004). Bilgi ekonomisi ve/ya yeni ekonomi'nin reddettikleri. Bilgi Dünyası, 5(1), 4873. 
Harrison, R. T. ve Leitch, M. C. (2000). Learning and organization in the knowledge-based information economy: Initial findings from a participatory action research case study. British Journal of Management, 11, 103-119.

Karunaratre, D. N. (2001). Issues in measuring the information economy. Journal of Economic Studies, 13(3), 51-68.

Kim, B., Barua, A. ve Whinston, B A. (2002). Virtual field experiments for a digital economy: A new search methodology for exploring an information economy. Decision Support Systems, $32,215-231$.

Kim, W. C. ve Mauborgne, R. (1997). Fair process: Managing in the knowledge economy. Harvard Business Review, 71-92. 